\title{
LINEing germ and embryonic stem cells' silencing of retrotransposons
}

\author{
Takashi Ishiuchi and Maria-Elena Torres-Padilla ${ }^{\mathbf{1}}$ \\ Institut de Génétique et de Biologie Moléculaire et Cellulaire, CNRS/INSERM U964, Université de Strasbourg, F-67404 Illkirch, \\ C.U. de Strasbourg, France
}

\begin{abstract}
Almost half of our genome is occupied by transposable elements. Although most of them are inactive, one type of non-long terminal repeat (LTR) retrotransposon, long interspersed nuclear element 1 (LINE1), is capable of retrotransposition. Two studies in this issue, Pezic and colleagues (pp. 1410-1428) and Castro-Diaz and colleagues (pp. 1397-1409), provide novel insight into the regulation of LINE1s in human embryonic stem cells and mouse germ cells and shed new light on the conservation of complex mechanisms to ensure silencing of transposable elements in mammals.
\end{abstract}

DNA transposons and retrotransposons occupy roughly half of our genome. Retrotransposons are classified in two main classes: long terminal repeat (LTR) and non-LTR retrotransposons. LTR retrotransposons include endogenous retroviruses and compose $\sim 8 \%$ of the human genome. Non-LTR retrotransposons, which contribute to $>30 \%$ of the human genome, include long interspersed nuclear elements (LINEs) and short interspersed nuclear elements (SINEs) (Cordaux and Batzer 2009). Although this view is changing as new regulatory roles have been ascribed to them, transposable elements (TEs) have long been considered to be junk DNA. Indeed, over the course of evolution, most TEs have accumulated mutations that interfered with their ability to retrotranspose and thus rendered them inactive. Nevertheless, some classes of TEs, like the non-LTR retrotransposon LINE-1 (L1), are still active and capable of retrotransposition in mammals. L1s are divided into subfamilies according to their evolutionary history; L1s seem to have evolved as a single lineage, but only young L1 subfamilies have the ability to retrotranspose. The youngest and human-specific L1 subfamily, L1Hs, is capable of retrotransposition, although it seems that other L1 subfamilies can also be transcribed because they have maintained promoter activity at their 5' untranslated regions (UTRs) (Brouha et al. 2003). The mutagenic potential of L1s implies that an effective

[Keywords: DNA methylation; evolution; KAP1; LINE1; piRNA; transposon]

${ }^{1}$ Corresponding author

E-mail metp@igbmc.fr

Article is online at http://www.genesdev.org/cgi/doi/10.1101/gad.246462.114. silencing mechanism must be in place to control their transcriptional activity; indeed, cells have evolved pathways to tightly regulate L1 expression. For example, in mouse embryonic stem cells (mESCs), loss of Suv39 enzymes or DNA methyltransferases (DNMTs) that catalyze the H3K9me3 mark and DNA methylation, respectively, leads to the derepression of L1, suggesting that histone modifications and DNA methylation have an important role in L1 silencing in mESCs (Matsui et al. 2010). It has not yet been established, however, whether the various L1 subfamilies are controlled by a common mechanism or whether different silencing mechanisms have evolved over time. In this issue of Genes \& Development, Castro-Diaz et al. (2014) and Pezic et al. (2014) provide new insights into the regulation of L1 subfamilies in human ESCs (hESCs) and mouse germ cells.

Castro-Diaz et al. (2014) examined the role of KAP1 binding on L1s in hESCs. KAP1, also known as TRIM28 (tripartite motif protein 28), is a cofactor of the DNAbinding KRAB [Krüppel-associated box domain]-containing zinc finger proteins (KRAB-ZFPs), which are thought to recruit KAP1 (KRAB-associated protein 1) to specific genomic sites. In addition, KAP1 can bind to HP1 $\alpha$ (heterochromatin protein $1 \alpha)$ and the SETDB1/ESET histone methyltransferase to catalyze the H3K9me3 mark found at constitutive heterochromatin, suggesting that KAP1 has an important role in creating a heterochromatin environment at specific genomic loci (Ryan et al. 1999; Schultz et al. 2002). In support of this, KAP1 depletion in mESCs induces a strong derepression of LTR retrotransposons such as IAP while only modestly affecting L1 expression (Rowe et al. 2010). Castro-Diaz et al. (2014) performed chromatin immunoprecipitation (ChIP) combined with deep sequencing (ChIP-seq) for KAP1 in hESCs and found that KAP1 is enriched at the $5^{\prime}$ UTR of L1s, where H3K9me3 is also enriched. Surprisingly, analysis of KAP1 enrichment for each L1 subfamily revealed that KAP1 binding was enriched on relatively young, but not the youngest, L1 subfamilies. This pattern was also found

(C) 2014 Ishiuchi and Torres-Padilla This article is distributed exclusively by Cold Spring Harbor Laboratory Press for the first six months after the full-issue publication date (see http://genesdev.cshlp.org/site/misc/ terms.xhtml). After six months, it is available under a Creative Commons License (Attribution-NonCommercial 4.0 International), as described at http://creativecommons.org/licenses/by-nc/4.0/. 
in mESCs, suggesting that KAP1 "discrimination" of subfamilies is conserved. How does KAP1 distinguish between discrete L1 subfamilies? The investigators provide evidence that a precise KRAB-ZFP recognizes specific L1 subfamilies through a putative DNA-binding motif. L1MdF2 and L1MdF3, two relatively young L1 subfamilies in mice, were found to be associated with GM6871, a KRABZFP. GM6871 depletion caused the specific derepression of L1s to which it binds. The investigators also depleted KAP1 in hESCs and found that KAP1-enriched L1s were also specifically derepressed, while the expression of the youngest L1Hs (on which KAP1 is not enriched) was not affected. The investigators then examined the role of DNA methylation on the regulation of L1 expression by knocking down the DNMTs DNMT1, DNMT3A, and DNMT3B in hESCs. Interestingly, the youngest L1s were significantly derepressed by the knockdown of DNMTs, suggesting that cells have adopted different mechanisms to silence distinct L1 subfamilies during evolution.

The maintenance of genomic integrity from one generation to the next requires the strict inhibition of retrotransposition in the germline. It has been clearly demonstrated that PIWI-interacting RNAs (piRNAs) have a crucial role in silencing retrotransposons in germ cells. Mouse PIWI family proteins, such as MILI and MIWI2, are responsible for the activity of piRNAs via RNA-directed mechanisms that are based on some degree of sequence similarity. Many piRNAs derive from retrotransposon elements, suggesting that piRNAs might be important for their targeted silencing. piRNA synthesis is required for DNA methylation on retrotransposon elements and for their transcriptional repression (Aravin et al. 2007; Kuramochi-Miyagawa et al. 2008). However, the involvement of histone modifications in this pathway in the mammalian germline has been unclear. Pezic et al. (2014) used ChIP to examine the enrichment of H3K9me3 on retrotransposon elements in germ cells. They found that $\mathrm{H} 3 \mathrm{~K} 9 \mathrm{me} 3$ was enriched on the $5^{\prime}$ end of $\mathrm{L} 1 \mathrm{~s}$ and tended to spread to upstream flanking regions. RNA sequencing (RNA-seq) profiling of piRNAs showed that piRNAs were also generated from these flanking regions of L1s, showing a correlation between $\mathrm{H} 3 \mathrm{~K} 9 \mathrm{me} 3$ distribution and piRNA production. The investigators then analyzed changes in $\mathrm{H} 3 \mathrm{~K} 9 \mathrm{me} 3$ enrichment using Miwi2 knockout mice that cannot produce piRNA (Carmell et al. 2007). L1s, in particular those from the young L1 families and from the Gf type that display the highest enrichment of H3K9me3 in wild-type germ cells, showed a decrease in H3K9me3 enrichment upon MIWI2 knockout. This reduction in $\mathrm{H} 3 \mathrm{~K} 9 \mathrm{me} 3$ levels was also found at the flanking regions upstream of L1s, suggesting a role for piRNAs on directing - and potentially also on spreading of-H3K9me3 over sites of piRNA production. In agreement with this observation, MIWI2 deficiency specifically resulted in derepression of these young L1 families. Importantly, the investigators noticed that full-length (and therefore transcriptionally active) copies of L1s had much higher enrichment of H3K9me3 marks compared with truncated copies of L1s, thus supporting a model in which piRNAs recognize nascent transcripts to alter the chromatin state through deposition of H3K9me3.

It was recently demonstrated that PIWI is responsible for the repression of $\mathrm{L} 1 \mathrm{Hs}$ retrotransposition in human induced pluripotent stem cells (iPSCs) but that this regulatory pathway is not functional in iPSCs from nonhuman primates (Marchetto et al. 2013). Together with the results from Castro-Diaz et al. (2014), it seems that the youngest L1Hs are suppressed by piRNA-dependent mechanisms, while KAP1 suppresses older L1s in human pluripotent cell types. On the other hand, Pezic et al. (2014) showed that the piRNA pathway is important for H3K9me3 acquisition on youngest L1s, which might be responsible for their silencing in mouse germ cells. It may be possible that piRNA-dependent H3K9me3 acquisition on young L1s in mouse germ cells is independent of KAP1, considering that Castro-Diaz et al. (2014) showed that KAP1 is not enriched at those young L1s in mESCs. Indeed, it is already known that Suv39s are involved in the suppression of L1 expression (Matsui et al. 2010). Taken together, this suggests that a combination of different mechanisms acts to silence transcriptionally active, full-length intact copies of L1s as opposed to older or truncated L1s that are less prone to activation. Future efforts will be directed at the identification of enzymes responsible for $\mathrm{H} 3 \mathrm{~K} 9 \mathrm{me} 3$ acquisition in germ cells in conjunction with the piRNA pathway as well as the determination of whether the H3K9me3 mark is indeed responsible for L1 silencing in germ cells. In addition, it might be intriguing to see whether the H3K9me3 mark is deposited onto L1Hs via a KAP1-independent and piRNA-dependent mechanism in hESCs, as has been observed in mouse germ cells.

\section{Acknowledgments}

Work in the Torres-Padilla laboratory is funded through EpiGeneSys Network of Excellence (NoE), a European Research Council Starting Grant, "NuclearPotency;" the EMBO Young Investigator Programme; and the Fondation Schlumberger pour l'Education et la Recherche. T.I. holds a post-doctoral Human Frontier Science Program fellowship.

\section{References}

Aravin AA, Sachidanandam R, Girard A, Fejes-Toth K, Hannon GJ. 2007. Developmentally regulated piRNA clusters implicate MILI in transposon control. Science 316: 744-747.

Brouha B, Schustak J, Badge RM, Lutz-Prigge S, Farley AH, Moran JV, Kazazian HH Jr. 2003. Hot L1s account for the bulk of retrotransposition in the human population. Proc Natl Acad Sci 100: 5280-5285.

Carmel MA, Girad A, van de Kant HJ, Bourch'his D, Bestor TH, de Rooij DG, Hannon GJ. 2007. MIWI2 is essential for spermatogenesis and repression of transposons in the mouse male germline. Dev Cell 12: 503-514.

Castro-Diaz N, Ecco G, Coluccio A, Kapopoulou A, Yazdanpanah B, Friedli M, Duc J, Jang SM, Turelli P, Trono D. 2014. Evolutionally dynamic L1 regulation in embryonic stem cells. Genes Dev (this issue). doi: 10.1101/gad.241661.114.

Cordaux R, Batzer MA. 2009. The impact of retrotransposons on human genome evolution. Nat Rev Genet 10: 691-703. 
Kuramochi-Miyagawa S, Watanabe $\mathrm{T}$, Gotoh $\mathrm{K}$, Totoki $\mathrm{Y}$, Toyoda A, Ikawa M, Asada N, Kojima K, Yamaguchi Y, Ijiri TW, et al. 2008. DNA methylation of retrotransposon genes is regulated by Piwi family members MILI and MIWI2 in murine fetal testes. Genes Dev 22: 908-917.

Marchetto MC, Narvaiza I, Denli AM, Benner C, Lazzarini TA, Nathanson JL, Paquola AC, Desai KN, Herai RH, Weitzman MD, et al. 2013. Differential L1 regulation in pluripotent stem cells of humans and apes. Nature 503: 525-529.

Matsui T, Leung D, Miyashita H, Maksakova IA, Miyachi H, Kimura H, Tachibana M, Lorincz MC, Shinkai Y. 2010. Proviral silencing in embryonic stem cells requires the histone methyltransferase ESET. Nature 464: 927-931.

Pezic D, Manakov S, Sachidanandam R, Aravin AA. 2014. piRNA pathway targets active LINE1 elements to establish the repressive $\mathrm{H} 3 \mathrm{~K} 9 \mathrm{me} 3$ mark in germ cells. Genes Dev (this issue). doi: $10.1101 / \mathrm{gad} .240895 .114$.

Rowe HM, Jakobsson J, Mesnard D, Rougemont J, Reynard S, Aktas T, Maillard PV, Layard-Liesching H, Verp S, Marquis J, et al. 2010. KAP1 controls endogenous retroviruses in embryonic stem cells. Nature 463: 237-240.

Ryan RF, Schultz DC, Ayyanathan K, Singh PB, Friedman JR, Fredericks WJ, Rauscher FJ 3rd. 1999. KAP-1 corepressor protein interacts and colocalizes with heterochromatic and euchromatic HP1 proteins: a potential role for Kruppelassociated box-zinc finger proteins in heterochromatin-mediated gene silencing. Mol Cell Biol 19: 4366-4378.

Schultz DC, Ayyanathan K, Negorev D, Maul GG, Rauscher FJ 3rd. 2002. SETDB1: a novel KAP-1-associated histone H3, lysine 9-specific methyltransferase that contributes to HP1mediated silencing of euchromatic genes by KRAB zincfinger proteins. Genes Dev 16: 919-932. 


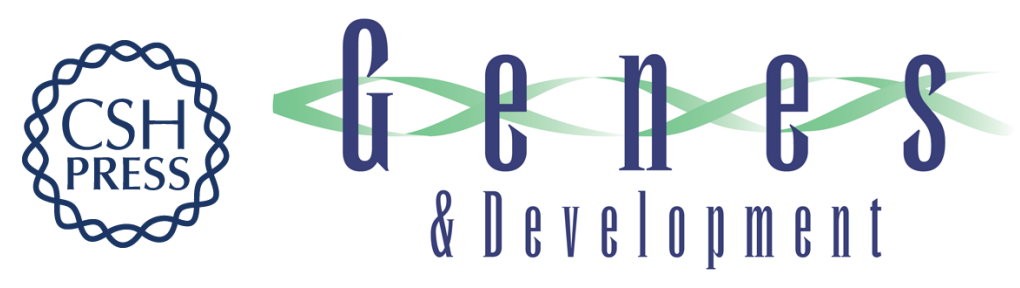

\section{LINEing germ and embryonic stem cells' silencing of retrotransposons}

Takashi Ishiuchi and Maria-Elena Torres-Padilla

Genes Dev. 2014, 28:

Access the most recent version at doi:10.1101/gad.246462.114

Related Content Evolutionally dynamic L1 regulation in embryonic stem cells

Nathaly Castro-Diaz, Gabriela Ecco, Andrea Coluccio, et al.

Genes Dev. July , 2014 28: 1397-1409 piRNA pathway targets active LINE1 elements

to establish the repressive $\mathrm{H} 3 \mathrm{~K} 9 \mathrm{me} 3$ mark in germ cells

Dubravka Pezic, Sergei A. Manakov, Ravi Sachidanandam, et al.

Genes Dev. July , 2014 28: 1410-1428

References This article cites 10 articles, 5 of which can be accessed free at:

http://genesdev.cshlp.org/content/28/13/1381.full.html\#ref-list-1

Articles cited in:

http://genesdev.cshlp.org/content/28/13/1381.full.html\#related-urls

Creative This article is distributed exclusively by Cold Spring Harbor Laboratory Press for the first Commons License six months after the full-issue publication date (see

http://genesdev.cshlp.org/site/misc/terms.xhtml). After six months, it is available under a Creative Commons License (Attribution-NonCommercial 4.0 International), as described at http://creativecommons.org/licenses/by-nc/4.0/.

Email Alerting
Service

Receive free email alerts when new articles cite this article - sign up in the box at the top right corner of the article or click here.

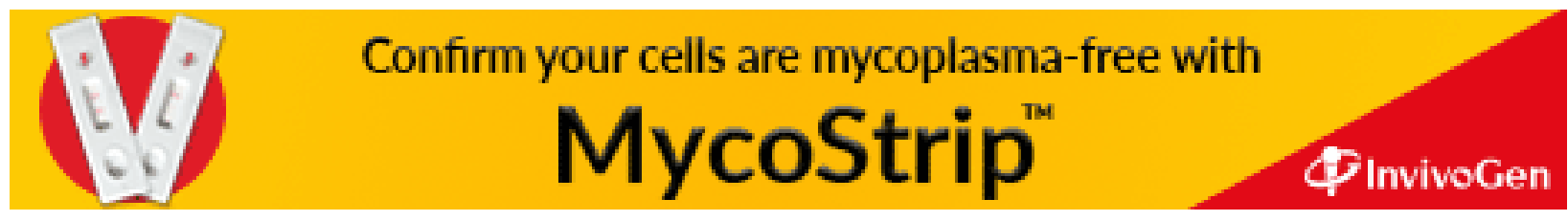

